Article

\title{
Do the Quota Applications for Women on Boards Improve Financial Performance
}

\author{
Sebahattin Yıldız ${ }^{1, * \mathbb{C}}$, Cebrail Meydan ${ }^{2}$, İlknur Taştan Boz ${ }^{3}$ and Önder Sakal ${ }^{4}$ \\ 1 Department of Management, Kafkas University, 36100 Kars, Turkey \\ 2 Department of Accounting and Finance, Adnan Menderes University, 09010 Aydın, Turkey; \\ cmeydan@adu.edu.tr \\ 3 Department of Management, Trakya University, 22030 Edirne, Turkey; ilknurtastan@trakya.edu.tr \\ 4 Department of Management, Binali Yıldırım University, 24100 Erzincan, Turkey; osakal@erzincan.edu.tr \\ * Correspondence: syildiz@kafkas.edu.tr; Tel.: +90-533-510-9717
}

Received: 14 September 2019; Accepted: 18 October 2019; Published: 24 October 2019

check for updates

\begin{abstract}
In the context of corporate governance principles, governments set regulations to increase the sustainable representation of women on boards. This paper seeks to answer the question of whether or not the application of compulsory or voluntary quotas for female board members improves firm performance. Based on difference analyses on the 2011 principles of the Capital Markets Board (CMB), we do not find significant differences between the companies with at least one female member on their board and those without any female board members in terms of financial performance indicators (return on asset (ROA), return on equity (ROE), market value/book value (MV/BV)). Based on difference analyses on the 2014 principles of the Capital Markets Board, we further find that the ROA of the companies with $25 \%$ and more female members is lower than the companies with $<25 \%$ female members. These results don't support the arguments of agency theory, because government regulations including the efforts of women to increase their representation rate on the board in a sustainable manner don't improve the accounting-based and market-based performance indicators of companies. If the company is successful, a quota for women cannot be imposed, because the obligation may result in a negative effect. Policymakers and practitioners may benefit from the knowledge that women may be improved and prepared for these positions and be accompanied with mentors before filling the compulsory or voluntary quota for women. It is not enough to increase the rate of women. The policy implication of the paper is that women must be equipped with the resources, authority, knowledge, and skills to perform well.
\end{abstract}

Keywords: woman of boards; gender discrimination; financial performance; corporate governance

\section{Introduction}

The representation level of women on boards is low [1]. However, the governments have started to make compulsory or voluntary recommendations and arrangements to improve sex discrimination in recent years [2-5]. These legal arrangements are based on the view that women will affect the understanding of corporate governance of the companies [6]. It is considered that both the effectiveness of the boards will increase, since they will have broader talent pools, and women will serve as an independent director because they do not belong to the "old boy club" [7]. When the literature indicating that board diversity has a significant role in the success of the companies is taken into consideration [8], it is important to examine the correlation between the composition of the board (gender diversity and size) and the performance of the company, especially quota applications.

Widely known corporate scandals such as Enron and WorldCom, as well as the failure of the financial institutions such as Lehman Brothers, have shaken trust in large corporations and brought up 
discussions about the corporate governance, especially the role and compositions of the boards [9]. In this context, some countries have introduced new corporate governance laws, while other countries have focused on the diversity of boards, especially gender diversity. As a result, the role of women on boards has gained more importance [10].

Following the failures of companies and recognition of the importance of corporate governance, the Sarbanes-Oxley Act was introduced in the US [11]. Moreover, other countries have also passed laws or regulatory guidelines that regulate corporate governance. The quotas were introduced in Finland in 2008, in France in 2010, in Italy in 2011, in India and the Netherlands in 2013, and in Germany in 2015 [2]. For example, Norway has a law stating that the rate of women on boards must be $40 \%$ mandatorily. Likewise, Spain has a law that regulates the quota for women on boards as comply or explain at $40 \%$. There are differences between the gender quotas of public companies and state-owned companies. For example, while the gender quota for public companies is $40 \%$, it is $50 \%$ for state-owned companies in Denmark [3,12]. There are quota practices for women in the countries with the highest rate of women on boards. For example: Denmark (50\%), Iceland (50\%), and Israel $(50 \%)[12,13]$.

While there are numerous studies investigating the effect of the variables related to the different compositions of boards on company performance [14-18], the number of the studies that examine the effect of compulsory and voluntary quota applications on the performance of companies is very limited. Therefore, this study is very important, and will fill an important gap in the literature. The first purpose of this study is to investigate the differences between the performances of the companies based on the presence of women on boards, as indicated in the 2011 principles [4] of the Capital Markets Board of Turkey. The second purpose of the study is to investigate the differences between the performances of the companies based on whether or not the rate of women on boards, as stated in the 2014 principles [5] of the Capital Markets Board of Turkey, has a certain percentage. The third purpose of the study is to reveal the correlations among the percentage of women on boards, the board size, and the performances of the companies.

This article emphasized that women's representation on boards should be sustainable. Thus, governments have developed the quota applications (communiques) for the sustainable representation of women on boards.

One of the goals of companies is sustainability. To achieve this goal, companies develop policies [19]. The sustainability of policies to increase women's representation on boards is also an ethical issue, since it will prevent gender discrimination. Thus, it will eliminate the glass ceiling barrier by balancing the gender distribution on boards.

Policies aimed at increasing the gender diversity on boards appear to be beneficial, balancing successfully the social cohesion and economic components of sustainable development [20], given that equal opportunities to women for sustainable economic development have recently been reflected in the policies of governments. Besides, governments' regulatory policies regarding discrimination on boards are important for the sustainable improvement of financial performance.

The headings relating to the formation of theoretical framework and hypothesis, research methodology, results, conclusion, and discussion have been explained in the following sections of this article.

\section{Formation of Theoretical Framework and Hypothesis}

\subsection{Women on the Boards}

A board is a strategic decision-making and executive body, which is selected by the shareholders and represents a company at the highest level [21]. The functions of the boards are as follows: monitoring and controlling the directors, providing information and consultancy to the directors, monitoring of the compliance with the relevant laws and arrangements, and linking an organization with its external environment [22]. 
The diversity of the board (for example; age, gender, ethnicity, education) is important for the structure of the board. The decisions to be taken by the diversified board will be of high quality and ensure that the demands of different groups are understood [23]. The diversity of the board can increase the independence of the board. The gender diversity is one of the most important variables of the diversity of the board [24].

The reasons for increasing the representation level of women on boards are these [25,26]: With the representation of women, the decisions taken have higher quality, the compliance with the laws increases, different perspectives and experiences are introduced, the environment becomes more understandable, and the decisions are made under ambiguity [27]. Female directors behave more cautiously and have an tendency to monitor and control carefully [26]. Gender diversity positively impacts a bank's environmental, social, and governance (ESG) performance [15]. Women put forward new ideas, attend the meetings more, and have the characteristics of the independent members [7].

\subsection{Financial Performance}

Financial performance can be defined as the evaluation of all the efforts made to realize the company's objectives [28]. Financial performance is the definition of the degree of the fulfillment of the enterprise's duties or the realization of the enterprise's objective by output or result obtained at the end of a certain period [29].

There are objective and subjective measurement methods. The most widely used five objective criteria to measure the company's performance are as follows [30]: ROA (return on asset), ROE (return on equity), and sales, which are accounting-based criteria; on the other hand, there are also the Tobin $\mathrm{q}$ and MV/BV (market value/book value), which are the market-based criteria. For example, Ganda and Milondzo [31] investigated how the intensity of these dimensions of carbon emissions (Scope 1, 2, and 1 and 2) impact corporate financial performance indicators (ROE, ROI, and return on sales-ROS). Ortas et al. [19] investigated the influence of organizations' board independence on corporate social performance (CSP), and the results showed that the independence of a company's board positively influences CSP.

\subsection{Theories Explaining the Correlation between the Existence of Women on Boards and Business Performance}

The study by Zahra and Pearce [32] is one of the most commonly referred studies about this topic in the literature. It is a review study suggesting the theoretical models and creating research questions about board. This study established relationships among the board qualities (composition, properties, process, structure), roles (service, strategic contribution, control), strategic outputs, and performance.

It is possible to mention different theories that explain the theoretical substructure of the correlation between the gender diversity on a board and the financial performance of its company. According to agency theory [33], if the diversity increases, the auditing and monitoring of the directors become easier. The independence of the board increases, and this situation increases the performance. According to resource dependence theory [34], if the diversity increases, it becomes easy to reach critical resources. The environmental dependence decreases by means of the cooperation with external organizations, and a support is provided. This situation increases the performance as well. According to human capital theory [9], if the diversity increases, the knowledge, experience, and creativity increase accordingly. In this case, the increase in the performance depends on the quality of the women [25]. According to social psychology theory [35], even if the diversity increases, the minorities can adopt the group norm. They cannot express their creative ideas to abstain from conflict. The ideas of an individual can change because of social impact, and this situation does not affect the performance. According to gender theories [36], even if the diversity increases, the performance is not affected due to symbolism or tokenism. Women are sometimes admitted to the management while the performance of the company decreases, and it is called a "glass-cliff" [37-39]. There are discrimination concepts emerging on the reflection of gender on corporations such as glass cliff, glass elevator, glass escalator, glass wall, glass labyrinth, tokenism, and double bind [40]. 


\subsection{The Studies in the Literature}

When the literature was examined, it was observed that the correlations between the representation of women on the boards and the indicators of the company's performance did not show consistent results. In some of the studies that examined the correlation between the rate of female members on boards and the company's performance, negative and significant correlations between these two variables were observed $[7,14]$, but positive and meaningful correlations between these two variables were observed in some other studies [41,42]. In some studies, no significant correlation between two variables was found $[16,43,44]$. For example, Ionascu et al. [20] examined the association between gender diversity on boards and firm performance for a European emerging market. They found that it has no significant impact on firm performance.

In the study by Atılgan [17], there was no correlation between financial performance (ROA and ROE) and the presentation of women on the boards, whereas a negative correlation was observed between financial performance (ROS and earnings before interest, taxes, depreciation and amortization-EBITDA margin) and the presentation of women on the boards. In the study by Karayel and Doğan [45], there was a positive correlation between ROA and the presentation of women on the boards, whereas there was no correlation between financial performance (ROE and Tobin Q) and the presentation of women on the boards. In the study by Taşkın and Evrim Mandacı [46], the presentation of women on the boards was associated with ROA negatively and with Tobin $\mathrm{q}$ positively, but no correlation with ROE was observed.

The agency theory enables controlling the directors in a suitable manner by means of the diversity on boards. Although it suggests a correlation between the diversity on board and the company's performance, the nature of this link is not clear [12].

Post and Byron in their study published in the Academy of Management Journal [47] conducted a meta-analysis of 140 articles examining these two variables. Accordingly, there is a positive correlation with the accounting-based indicators. If the shareholder protection index of the countries increases, this correlation further increases. The correlation with the market-based indicators is nearly zero. If gender parity score increases, so does this correlation. The presence of women on a board has a positive correlation with two points (control and attendance).

In the context of the corporate governance principles, the Capital Markets Board of Turkey (CMB) attempted to increase the rate of women on boards by publishing communiques in 2011 and 2014. In the communiqué in 2011, it was recommended that at least one female member should be present on the board [4], and in the communiques in 2014, it was recommended that the rate of female members should be $25 \%$ and more [5].

The following hypotheses were developed as a result of the aforementioned theoretical framework and empirical studies.

Hypothesis 1. Financial performance ( $R O A, R O E, M V / B V$ ) of a company that has at least one female member on the board differs from that ( $R O A, R O E, M V / B V)$ of a company that does not have any female members on the board (2011 Communiques of the Capital Markets Board). (In the 2011 communiques of the Capital Boards Market of Turkey, in the context of corporate governance principles, it is recommended that the number of female members on the board of the companies should be at least 1 [4]).

Hypothesis 2. Financial performance ( $R O A, R O E, M V / B V)$ of a company whose percentage of women on its board is $25 \%$ and more differs from that (ROA, ROE, MV/BV) of a company whose percentage of women on its board is less (2014 Communiques of the Capital Markets Board). (In the 2014 communiques of the Capital Boards Market of Turkey, in the context of corporate governance principles, it is recommended that the percentage of female members on the board should be $25 \%$ and more [5]).

Hypothesis 3. There is a correlation between the percentage of women on the board and the company's performance criteria. 


\subsection{Board Size}

The board size expresses the number of members on boards [48]. While the matter regarding the ideal size of the board is disputable, contextual variables such as age and the active size of the company are effective in determining the board size. While the decision quality improves due to the expertise in big boards, coordination-related problems can be encountered [49,50].

It was observed that there are different results in the studies examining the correlation between the board size and the performance of the company. While some studies have negative correlations $[49,51]$, some have positive correlations [52]. Studies indicating no correlation were also observed [53,54]. In the study by Lam and Lee [55], a negative correlation was observed between the board size and ROA, but no correlation with ROE was observed.

The following hypothesis was developed as a result of the aforementioned theoretical foundations and empirical studies.

Hypothesis 4. There are significant correlations between the board size and the company's performance criteria.

\section{Research Methodology}

\subsection{Sample Selection and Data Collection}

The companies registered in Borsa Istanbul (BIST) are part of the scope of this study. Secondary data were obtained by using the 2016 activity reports of 389 companies registered in Borsa Istanbul and on the Public Disclosure Platform [56].

In this study, the gender diversity (the presence and rate of women) on the board and the board size were used as independent variables; on the other hand, the return on asset (ROA), return on equity (ROE) and the market-to-book value ratio (MV/BV) of the companies were used as dependent variables. The age and size of the company were also used as the control variables. Table 1 shows the variables and their means.

Table 1. Variables and their means.

\begin{tabular}{cc}
\hline $\begin{array}{c}\text { (Dependent Variable) } \\
\text { Financial Performance Criteria }\end{array}$ & Means \\
\hline $\begin{array}{c}\text { Return on Assets (ROA) }(\%) \\
\text { Return on Equity (ROE) }(\%) \\
\text { Market to Book Value Ratio }(\mathrm{MV} / \mathrm{BV})\end{array}$ & $\begin{array}{c}\text { Ratio of Annual Net Profit to Total Assets } \\
\text { Ratio of Annual Net Profit to Equity } \\
\text { Ratio of Market Value to Book Value }\end{array}$ \\
\hline $\begin{array}{c}\text { Independent Variables } \\
\text { (Gender Diversity) }\end{array}$ & Means \\
\hline $\begin{array}{c}\text { Rate of Female Members } \\
\text { Board Size }\end{array}$ & $\begin{array}{c}\text { Ratio of the Number of Female Members to the Board Size } \\
\text { Total Number of Members on Board } \\
\text { Presence of Women }\end{array}$ \\
\hline Control Variables & Definitions \\
\hline $\begin{array}{c}\text { Age of Company } \\
\text { Size of Company }\end{array}$ & $\begin{array}{c}\text { How Many Years Has the Company Existed? } \\
\text { Value of The Company's Total Assets }\end{array}$ \\
\hline
\end{tabular}

\subsection{Analyses Used in the Study}

In this study, firstly, descriptive analyses about variables were performed (Table 2). Afterwards, an independent samples t-test was conducted to compare the differences between the financial performance criteria of the companies according to whether or not there were women on the board (Table 3). In addition, an independent samples t-test was also conducted to compare the differences between the financial performance criteria of the companies according to the rate (percentage) of women on boards (Table 4). 
Table 2. Descriptive statistics.

\begin{tabular}{ccccc}
\hline Variables & Min & Max & Mean & Std. Deviation \\
\hline Board Size & 3 & 15 & $7(2723 / 389)$ & 2.25 \\
Number of Women & 0 & 5 & $0.97(376 / 389)$ & 1.01 \\
ROA & -1.6 & 1.97 & 0.03 & 0.2 \\
ROE & -48.85 & 17.07 & -0.15 & 3.08 \\
MV/BV & -19.972 & 1814.5414 & 7.01 & 92.24 \\
Age of Company & 3 & 92 & 33.54 & 17.29 \\
Total Assets (TL) & 69,250 & $311,623,835,494$ & $7,654,961,803$ & $36,988,890,911$ \\
Women \% & 0 & 100 & 15 & 16 \\
\hline
\end{tabular}

Note: ROA: Return on Assets; ROE: Return on Equity; MV/BV: Market to Book Value Ratio.

Table 3. Differences in the financial performance based on the presence of the female members on the board (2011 Criteria, CMB, Turkey).

\begin{tabular}{lcccccc}
\hline Variables & Compliance & Number & Means & Standard Deviation & T & Sig \\
\hline \multirow{2}{*}{ ROA } & No & 158 & 0.02 & 0.19 & 0.003 & 0.77 \\
& Yes & 231 & 0.01 & 0.21 & & \\
ROE & No & 158 & 0.008 & 0.59 & 3.2 & 0.38 \\
& Yes & 231 & -0.27 & 3.9 & & \\
MV/BV & No & 158 & 1.84 & 2.68 & 2.88 & 0.36 \\
& Yes & 231 & 10.5 & 119.6 & &
\end{tabular}

Note: ROA: Return on Assets; ROE: Return on Equity; MV/BV: Market to Book Value Ratio; No: There is not at least one woman on the board; Yes: There is at least one woman on the board, CMB: Capital Markets Board of Turkey.

Table 4. Differences in the financial performance based on the presence of $25 \%$ and more female members on boards (2014 Criteria, CMB, Turkey).

\begin{tabular}{ccccccc}
\hline Variables & Compliance & Number & Means & Standard Deviation & $\mathbf{t}$ & Sig \\
\hline \multirow{2}{*}{ ROA } & No & 297 & 0.03 & 0.19 & 1.6 & 0.02 \\
& Yes & 92 & -0.02 & 0.23 & & \\
\multirow{2}{*}{ ROE } & No & 297 & 1.18 & 3.5 & 1.3 & 0.74 \\
& Yes & 92 & -0.06 & 0.06 & & \\
MV/BV & No & 297 & 8.7 & 105.5 & 1.34 & 0.49 \\
& Yes & 92 & 1.3 & 2.6 & & \\
\hline
\end{tabular}

Note: ROA: Return on Assets; ROE: Return on Equity; MV/BV: Market to Book Value Ratio; No: The rate of women on board is not $25 \%$ and more; Yes: The rate of women on board is $25 \%$ and more; CMB: Capital Markets Board of Turkey.

The accounting-based (ROA and ROE) and market-based (MV/BV) performance measurements were used for financial performance criteria of companies. Then, the correlations between the rate (percentage) of women on boards and the ROA, ROE, and MV/BV ratio were examined (Table 5).

Table 5. Correlation analysis.

\begin{tabular}{lcccccccc}
\hline \multicolumn{1}{c}{ Variables } & Means & Standard Deviation & $\mathbf{1}$ & $\mathbf{2}$ & $\mathbf{3}$ & $\mathbf{4}$ & $\mathbf{5}$ & $\mathbf{6}$ \\
\hline 1. Board Size & 7 & 2.25 & 1 & & & & & \\
2. Age & 33.54 & 17.29 & $0.35^{* * *}$ & 1 & & & & \\
3. Assets (TL) & $7,654,961,803$ & $36,988,890,911$ & $0.29^{* * *}$ & $0.26^{* * *}$ & 1 & & & \\
4. Women $\%$ & 15 & 16 & $-0.16^{* *}$ & $-0.14^{* *}$ & -0.02 & 1 & & \\
5. ROA & 0.03 & 0.20 & $\mathbf{0 . 0 7}$ & $0.12^{*}$ & -0.01 & $-\mathbf{0 . 0 9}$ & 1 & \\
6. ROE & -0.15 & 3.08 & $\mathbf{0 . 0 0 4}$ & 0.02 & 0.01 & $-\mathbf{0 . 0 1}$ & $0.27^{* * *}$ & 1 \\
7. MV/BV & 7.01 & 92.24 & $\mathbf{0 . 0 9}$ & $0.18^{* * *}$ & -0.01 & $\mathbf{0 . 0 0 8}$ & $0.53^{* * *}$ & $0.24^{* * *}$ \\
\hline
\end{tabular}

Note: ROA: Return on Assets; ROE: Return on Equity; MV/BV: Market to Book Value Ratio Level.

Significant Correlations: ${ }^{* *}, 1 \%$; ${ }^{* *}, 5 \% ; *, 10 \%$. 


\section{Empirical Results and Discussion}

\subsection{Descriptive Statistics}

Table 2 shows the results of descriptive analyses related to the board size of the company, the number of women, the return on assets, the return on equity, the market to book value ratio, the age of the company, the total assets of the company, and the percentage of women. The total board size of 389 companies was 2.723; the total number of women was 376; the average board size was 7; the average number of women was 0.97 , and the average percentage of women was $15 \%$.

\subsection{Difference Analyses for Hypothesis Tests}

In this study, an independent samples t-test was conducted to test Hypothesis 1 . Accordingly, there were 231 (59\%) companies that complied with the voluntary quota (advisory) recommendation of at least one female member on board, as indicated in the 2011 principles of the $\mathrm{CMB}$, and as shown in Table 3. A total of 158 companies did not comply with the 2011 principles of the CMB, and there is not even one female member on their boards. Accordingly, the financial performance criteria (ROA, ROE, $\mathrm{MV} / \mathrm{BV}$ ) of a company that had at least one female member on its board did not significantly differ from those (ROA, ROE, MV/BV) of a company that did not have any female members on its board $(p>0.05)$. Therefore, Hypothesis 1 was not supported.

In this study, an independent samples t-test was conducted to test Hypothesis 2. Accordingly, 92 (24\%) companies complied with the voluntary quota (advisory) recommendation of the presence of $25 \%$ and more female members on board, as indicated in the 2014 principles of the CMB, and as shown in Table 4. A total of 297 companies did not comply with the 2014 principles of the $\mathrm{CMB}$, and the rate of women on their boards was not $25 \%$ or more. Accordingly, ROE and MV/BV, among the financial performance criteria, of the companies that complied with the 2014 principles of the CMB did not significantly differ from those of the companies that did not comply with the 2014 principles of the CMB ( $p$ > 0.05). On the other hand, ROA significantly decreased in the companies that complied with the 2014 principles of the $\mathrm{CMB}$, rather than the companies that did not comply with the 2014 principles of the CMB of Turkey $(p<0.05)$. Therefore, Hypothesis 2 was not partially supported.

\subsection{Correlation Analyses for the Hypothesis Tests}

In this study, correlation analyses were conducted to test Hypothesis 3 and Hypothesis 4. The significant correlations between the percentage of women on boards and the financial performance criteria were not observed, as shown in Table 5. Accordingly, Hypothesis 3 was not supported. Similarly, the significant correlations between the board size and the financial performance criteria were not observed as well. Accordingly, Hypothesis 4 was not supported.

\subsection{Discussion}

This study was designed by considering the 2016 data of 389 companies registered in the CBM in Turkey so as to examine the correlations between the compositions of the board (gender diversity and board size) and the performance of the company. This study aimed to examine the differences in company performance regarding the practice of voluntary quota for women.

Accordingly, no correlation between the percentage of women on boards and the financial performance criteria was determined. These results are consistent with some studies in the literature $[12,16,18,20,45,57,58]$. Brindelli et al. [15] diversely showed that the relationship between women on boards and a bank's ESG performance is an inverted U-shape. They found that only gender-balanced boards positively impact a bank's performance for sustainability.

Significant correlations between the board size and the company's performance criteria were not observed. The results of this study are consistent with the studies in the literature [53-55].

The performance of the companies with at least one female member on their boards did not differ from that of the companies without any female members on their boards according to the 2011 criteria 
of the CMB. Therefore, it is recommended that increasing the number of women or the quality of women selected must be taken into consideration.

Our finding can provide different insights about agency theory, resource dependence theory, human capital theory, social psychology theory, and gender theories. They push forward our understanding. For example, different theories that explain the absence of the correlation between the gender diversity on board and the performance of the company can be mentioned: Agency theory was not supported. The diversity increased, but the performance remained the same, since there may be deficiencies in terms of monitoring and auditing the directors. The presence of independent female members is recommended. Resource dependence theory was not supported. The diversity increased, but the performance remained the same due to the difficulties in accessing critical resources. It is recommended to assign women, who will enable accessing critical resources, to the boards. Human capital theory was not supported. The diversity increased, but the performance remained the same, since quality women were not assigned to the management. It is recommended to consider the quality of women (education, experience, etc.) to be assigned to the management. Social psychology theory was supported. The diversity increased; however, the performance remained the same, since women adopted the group norm. Gender theories were supported. The diversity increased; however, the performance remained the same, since it is based on tokenism. Governments or regulators should create different regulations or practices according to this study. We may recommend the above-mentioned suggestions to improve the current regulation or practice.

According to the criteria of the CMB in 2014, there is a difference in ROA between the companies with $25 \%$ and more women on their boards, and those with a lower percentage of women on their boards, whereas the ROE and MV/BV do not change between these companies. The increase in the rate of women decreases the ROA. Women must be provided with certain trainings and prepared for these positions when they are admitted to the board. It can be related to the board structure of Turkey. In Turkey, ownership is not various, but it does pertain to a few families. Therefore, principal agency theory can work in a different manner.

For telling a richer story and linking to more literature, we need to discuss more relevant channels: Market competition as a governance mechanism [59], the interactions between the executives, such as mutual monitoring among the executives [60], mutual monitoring and agency problems [61], external interactions between CEOs in the industry tournament [62], inside debt as governance [63], or compensation incentives [64].

\section{Conclusions, Recommendations, and Limitations}

Sustainable social participation policies such as compulsory gender quotas on boards ensure financial sustainability and produce positive economic outputs for shareholders [20]. The original value and contribution of this study is its demonstration that women are being appointed to boards without being ready, just to fill compulsory or voluntary female member quotas. This situation states tokenism as a career barrier for women, that is to say, compliance with the principles of corporate governance. In the context of gender theories, although the representation level of the women on boards has increased, they cannot make important decisions or serve in strategic commissions due to tokenism. In addition, according to social psychology theory, women can adopt the group norm; thus, the financial performance does not change.

In conclusion, these recommendations can be taken into account for further research intentions: Business systems can be taken into consideration, since the corporate governance mechanisms of the countries are affected from the differences in National Business Systems/Mode of Organization [65]. This result may have emerged because Turkey has the state-dependent business system. The educational status of the board members (doctor, post-graduate or engineer, economist, lawyer) can be examined. Indices such as the Blau Index and Shannon Index can be used for assessing the gender diversity on boards, and different conclusions can be drawn. In addition to the presence of any female members on boards, there must be balance between female and male members. The diversity on a company's board 
can affect its performance through the company's reputation or innovation, rather than directly affecting it. Young members on boards can affect the performance of the company much more. The effect of variables such as a female CEO, a female chairman of the board, an independent female member, or a female member from the family on the performance can be examined. Before filling a voluntary or advisory quota for women, women may be improved and prepared for these positions, and could be accompanied with mentors. When sector or company variables are controlled, different results may be obtained. It is not enough to increase the rate of women; women must be assigned to the strategic commissions, granted authority, given information, and be equipped to perform these actions. They must make decisions, take initiative, and use power. If the company is successful, a quota for women cannot be imposed. If there is a quota, there is also an obligation that may result in a negative effect. If there is an obligation, there will be ineffective councils. Women with excessive control habits can cause negative effects. Contextual variables such as the Strength of Investor Protection Index and Global Gender Gap Score suggested by Post and Byron [47] can be used. Women deserve to be on boards with their human capital and information, and if there are women on boards, the governance can be better.

There are some limitations of this research. The first limitation is that this cross-sectional study was conducted only with one-year data. It is recommended to make longer-term research studies in the future. The second limitation is that the ROA, ROE, and MV/BV ratios were used for the company's performance criteria. Different criteria can be employed in the future studies. Tokenism will be eliminated by training women for top-level management positions, rather than imposing compulsory or voluntary quotas.

Author Contributions: This article is the result of the joint efforts of the authors, who equally contributed to the work. Conceptualization, S.Y., and C.M.; Data curation, C.M.; Formal analysis, S.Y. and İ.T.B.; Investigation, Ö.S.; Methodology, S.Y. and Ö.S.; Supervision, S.Y. and C.M.; Validation, İ.T. and Ö.S.; Visualization, S.Y., C.M., İ.T.B. and Ö.S., Writing—original draft, S.Y. and C.M.; Writing—review and editing, İ.T.B. and Ö.S.

Funding: This research received no external funding.

Conflicts of Interest: The authors declare no conflict of interest.

\section{References}

1. Elsaid, E.; Ursel, N.D. Re-examining the glass cliff hypothesis using survival analysis: The Case of female CEO tenure. Br. J. Manag. 2018, 29, 156-170. [CrossRef]

2. Catalyst. Women on Corporate Boards: Quick Take. 2018. Available online: https://www.catalyst.org/ research/women-on-corporate-boards/ (accessed on 9 September 2019).

3. MSCI. Women on Boards: Progress Report 2017. Available online: https://www.msci.com/www/researchpaper/women-on-boards-progress-report/0806530251 (accessed on 9 September 2019).

4. Capital Markets Board. Sermaye Piyasası Kurulu. Kurumsal Yönetim Ilkelerinin Belirlenmesine ve Uygulanmasına Ilişkin Tebliğ, (Seri: IV, No: 56). 2011. Available online: http://www.spk.gov.tr/Sayfa/Dosya/ 66 (accessed on 8 August 2019). (In Turkish)

5. Capital Markets Board. Sermaye Piyasası Kurulu. Kurumsal Yönetim Tebliği (II-17.1), 2014. Available online: http://www.resmigazete.gov.tr/eskiler/2014/01/20140103-3.htm (accessed on 8 August 2019). (In Turkish)

6. Francoeur, C.; Labelle, R.; Sinclair-Desgagne, B. Gender diversity in corporate governance and top management. J. Bus. Ethics 2008, 81, 83-95. [CrossRef]

7. Adams, R.; Ferreira, D. Women in the boardroom and their impact on governance and performance. J. Financ. Econ. 2009, 94, 291-309. [CrossRef]

8. Erhardt, N.L.; Werbel, J.D.; Shrader, C.B. Board of director diversity and firm financial performance. Corp. Gov. 2003, 11, 102-111. [CrossRef]

9. Terjesen, S.; Sealy, R.; Singh, V. Women directors on corporate boards: A review and research agenda. Corp. Gov. Int. Rev. 2009, 17, 320-337. [CrossRef]

10. Vinnicombe, S.; Singh, V.; Burke, R.J.; Bilimoria, D.; Huse, M. (Eds.) Women on Corporate Boards of Directors: International Research and Practice; Edward Elgar: London, UK, 2009. 
11. Sarbanes-Oxley Act. 2002. Available online: https://legcounsel.house.gov/Comps/Sarbanes-oxley\%20Act $\%$ 20Of\%202002.pdf (accessed on 9 September 2019).

12. Carter, D.A.; D'Souza, F.; Simkins, B.J.; Simpson, W.G. The gender and ethnic diversity of US boards and board committees and firm financial performance. Corp. Gov. Int. Rev. 2010, 18, 396-414. [CrossRef]

13. Corporate Women Directors International. Available online: https://globewomen.org/CWDINet/ (accessed on 9 September 2019).

14. Alvarez, I.G.; Garcia-Sanchez, I.M.; Rodriguez-Dominguez, L. The influence of gender diversity on corporate performance. Span. Account. Rev. 2010, 13, 53-88.

15. Birindelli, G.; Dell'Atti, S.; Iannuzzi, A.P.; Savioli, M. Composition and activity of the board of directors: Impact on ESG performance in the banking system. Sustainability 2018, 10, 4699. [CrossRef]

16. Darmadi, S. Board diversity and firm performance: The Indonesian evidence. Corp. Ownersh. Control J. 2010, 8, 1627-1637. [CrossRef]

17. Atılgan, Ö. Yönetim kurulu büyüklüğü, bağımsız üye oranı ve kadın üye oranı ile finansal performans ilişkisi. Dokuz Eylül Üniversitesi İktisadi Ve İdari Bilimler Fakültesi Derg. 2017, 32, 315-354. (In Turkish)

18. Haslam, S.A.; Michelle, K.R.; Clara, K.; Grzegorz, T.; Cate, A. Investing with prejudice: The relationship between women's presence on company boards and objective and subjective measures of company performance. Br. J. Manag. 2010, 21, 484-497. [CrossRef]

19. Ortas, E.; Álvarez, I.; Zubeltzu, E. Firms' Board Independence and Corporate Social Performance: A Meta-Analysis. Sustainability 2017, 9, 1006. [CrossRef]

20. Ionascu, M.; Ionascu, I.; Sacarin, M.; Minu, M. Women on Boards and Financial Performance: Evidence from a European Emerging Market. Sustainability 2018, 10, 1644. [CrossRef]

21. Baysinger, B.D.; Butler, H.N. Corporate governance and the board of directors: Performance effects of changes in board composition. J. Law Econ. Organ. 1985, 1, 101-124.

22. Van den Berghe, L.A.A.; Baelden, T. The monitoring role of the board: One approach does not fit all. Corp. Gov. 2005, 13, 680-690. [CrossRef]

23. Pfeffer, J.; Salancik, G.R. The External Control of Organizations: A Resource Dependence Perspective; Stanford Business Books: Stanford, CA, USA, 2003.

24. Miller, T.; Triana, M. Demographic diversity in the boardroom: Mediators of the board diversity-firm performance relationship. J. Manag. Stud. 2009, 46, 755-786. [CrossRef]

25. Smith, N.; Valdemar, S.; Mette, V. Do women in top management affect firm performance? A panel study of 2,500 Danish firms. Int. J. Product. Perform. Manag. 2006, 55, 569-593. [CrossRef]

26. Campbell, K.; Minguez-Vera, A. Gender diversity in the boardroom and firm financial performance. J. Bus. Ethics 2008, 83, 435-451. [CrossRef]

27. Robinson, G.; Dechant, K. Building a business case for diversity. Acad. Manag. Exec. 1997, 11, $21-31$. [CrossRef]

28. Akal, Z. İşletmelerde Performans ölçü ve Denetimi; MPM: Ankara, Turkey, 1992. (In Turkish)

29. Yıldız, S. İşletme performansının ölçümü üzerine bankacılık sektöründe bir araştırma. Erciyes Üniversitesi İktisadi Ve İdari Bilimler Fakültesi Derg. 2010, 36, 179-193. (In Turkish)

30. Yıldiz, S.; Karakaş, A. Defining methods and criteria for measuring business performance: A comparative research between the literature in Turkey and foreign. Procedia-Soc. Behav. Sci. 2012, 58, 1091-1102.

31. Ganda, F.; Milondzo, K.S. The Impact of Carbon Emissions on Corporate Financial Performance: Evidence from the South African Firms. Sustainability 2018, 10, 2398. [CrossRef]

32. Zahra, S.A.; Pearce, J.A., II. Boards of directors and corporate financial performance: A review and integrative model. J. Manag. 1989, 15, 291-334. [CrossRef]

33. Jensen, M.C.; Meckling, W. Theory of the firm: Managerial behavior, agency costs and ownership structure. J. Financ. Econ. 1976, 3, 305-360. [CrossRef]

34. Pfeffer, J.; Salancik, G.R. The External Control of Organizations: A Resource Dependence Perspective; Harper \& Row: New York, NY, USA, 1978.

35. Westphal, J.D.; Milton, L.P. How experience and network ties affect the influence of demographic minorities on corporate boards. Adm. Sci. Q. 2000, 45, 366-398. [CrossRef]

36. Kanter, R. Men and Women of the Corporation; Basic Books: New York, NT, USA, 1977.

37. Ryan, M.; Haslam, A. What lies beyond the glass ceiling?: The glass cliff and the potential precariousness of women's leadership positions. Hum. Resour. Manag. Int. Dig. 2006, 14, 3-5. [CrossRef] 
38. Yıldız, S.; Vural, M.F. A cultural perspective of the glass cliff phenemenon. Ege Acad. Rev. 2019, 19, 309-321.

39. Yıldız, S.; Sakal, Ö.; Alhas, F.; Kosa, G. The perception of glass cliff: A research between students studying in Kafkas University. J. Mehmet Akif Ersoy Univ. Econ. Adm. Sci. Fac. 2019, 6, 423-438.

40. Yıldız, S. A model proposal on consequences of discrimination concepts emerging on the reflection of gender on corporations. Eskişehir Osman. Univ. J. Soc. Sci. 2017, 18, 121-138.

41. Ocak, M. Yönetim kurulu ve üst yönetimde yer alan kadınların finansal performansa etkisi: Türkiye'ye ilişkin bulgular. Muhasebe Ve Finans. Derg. 2013, 60, 107-126. (In Turkish)

42. Otluoğlu, E.; Sarı, E.S.; Otluoğlu, K.Ö.Ç. Yönetim kurulu çeşitliliğinin finansal performansına etkisi: BIST 100 üzerine bir araştırma. Uluslararası Sos. Araştırmalar Derg. 2016, 46, 749-758. (In Turkish)

43. Karoğlu, E. Vekalet kuramı perspektifinden yönetim kurulu kompozisyonunun finansal performans üzerindeki etkisi: BIST imalat sektörü örneği. Balk. Ve Yakın Doğu Sos. Bilimler Derg. 2016, 2, 65-77. (In Turkish)

44. Yağlı, İ; Ünlü, U. Yönetim kurulu çeşitliliği firma performansını etkiler mi? In Proceedings of the International Conference of Research in Social Science and Education, Antalya, Turkey, 14-16 October 2016; pp. 1627-1637. (In Turkish).

45. Karayel, M.; Doğan, M. Yönetim kurulunda cinsiyet çeşitliliği ve finansal performans ilişkisi: BİST 100 şirketlerinde bir araştırma. Süleyman Demirel Üniversitesi İktisadi Ve İdari Bilimler Fakültesi Derg. 2014, 19, 75-88. (In Turkish)

46. Taşkın, F.D.; Evrim Mandacı, P. Şirket yönetim kurulundaki kadın üyelerin firma performansına etkisi. İşletme Fakültesi Derg. 2017, 18, 29-45. (In Turkish)

47. Post, C.; Byron, K. Women on boards and firm financial performance: A Meta-analysis. Acad. Manag. J. 2015, 58, 1546-1571. [CrossRef]

48. Dalton, R.D.; Jonathan, L.J.; Alan, E.E. Number of directors and financial performance: A meta-analysis. Acad. Manag. J. 1999, 42, 674-686.

49. Yermack, D. Higher market valuation of companies with a small board of directors. J. Financ. Econ. 1996, 40, 185-211. [CrossRef]

50. Cheng, S. Board size and the variability of corporate performance. J. Financ. Econ. 2008, 87, 157-176. [CrossRef]

51. Koerniadi, H.; Tourani-Rad, A. Does board independence matter? Evidence from New Zealand. Australas. Account. Bus. Financ. J. 2012, 6, 3-18.

52. Swastika, D.L.T. Corporate governance, firm size, earnings management: Evidence in Indonesia stock exchange. Iosr J. Bus. Manag. 2013, 10, 77-82. [CrossRef]

53. Kiel, G.C.; Nicholson, G.J. Board composition and corporate performance: How the Australian experience informs contrasting theories of corporate governance. Corp. Gov. Int. Rev. 2003, 11, 189-205. [CrossRef]

54. Uchida, K. Does corporate board downsizing increase shareholder value? Evidence from Japan. Int. Rev. Econ. Financ. 2011, 20, 562-573. [CrossRef]

55. Lam, Y.T.; Lee, S.K. CEO duality and firm performance: Evidence from Hong Kong. Corp. Gov. Int. J. Bus. Soc. 2008, 8, 299-316.

56. Public Discource Platform. Available online: https://www.kap.org.tr/tr/ (accessed on 9 September 2019).

57. Shukeri, S.N.; Shin, O.W.; Shaari, M.S. Does board of director's characteristics affect firm performance? Evidence from Malaysian public listed companies. Int. Bus. Res. 2012, 5, 120-127. [CrossRef]

58. Mohammad, S.J.; Abdullatif, M.; Zakzouk, F. The effect of gender diversity on the financial performance of Jordanian banks. Acad. Account. Financ. Stud. J. 2018, 22, 1-11.

59. Giroud, X.; Mueller, H.M. Corporate governance, product market competition, and equity prices. J. Financ. 2011, 66, 563-600. [CrossRef]

60. Li, Z.F. Mutual monitoring and corporate governance. J. Bank. Financ. 2014, 45, 255-269.

61. Li, Z.F. Mutual Monitoring and Agency Problem. 2018. Available online: https://www.researchgate.net/ publication/272305464_Mutual_Monitoring_and_Agency_Problems (accessed on 30 September 2019).

62. Coles, J.F.; Li, Z.F.; Wang, A.Y. Industry tournament incentives. Rev. Financ. Stud. 2018, 31, 1418-1459. [CrossRef]

63. Li, Z.F.; Lin, S.; Sun, S.; Tucker, A. Risk-adjusted inside debt. Glob. Financ. J. 2018, 35, 12-42. [CrossRef] 
64. Core, J.; Guay, W. The use of equity grants to manage optimal equity incentive levels. J. Account. Econ. 1999, 28, 151-184. [CrossRef]

65. Whitley, R. The social construction of business systems in East Asia. Organ. Stud. 1991, 12, 1-28. [CrossRef] 